\title{
CULTURE AS A TOOL FOR SCHOOL IMPROVEMENT: THE CASE OF CHILDREN'S SOCIALISATION CENTRES
}

\author{
Simona Bieliune
}

Vilnius University, Lithuania, simona.bieliune@ntakd.lt

\begin{abstract}
The concern for delinquent children's social and emotional development in closed institutions is a significant topic in educational research. This shows the need to improve the existing re-socialisation practice. Despite the fact that school effectiveness and school improvement researches theoretically have different general purposes and value bases, educational effectiveness and improvement paradigm involves both trends, which are combined by the same aspects: scientific approach and empirical data based on educational settings; knowledge of how to improve the school practice; and use of this knowledge for social purposes. In this context, the concept of the school culture is one of the main variables that allow us to answer how to address the needs of all children and improve their academic or social outcomes. The aim of this article is to illustrate the cultural characteristics of children's socialisation centres as specific schools and to identify the guidelines for improving their performance. The mission of children's socialisation centres is to re-socialise delinquent behaviour of children and to help them to integrate into the society. Quantitative data for measuring the school culture is obtained from the survey that was conducted using the School Culture Inventory (Maslowski, 2001). This instrument is based on the Competing Values Framework (Cameron, Quinn, 2011) consisting of four dimensions, which are labelled by human relations, open systems, rational goal and internal process orientation. The theoretical value of the survey is the analysis of school culture in terms of successful re-socialisation. The cultural profiles of these schools showed the priorities that require practical changes.
\end{abstract}

Keywords: school, performance, culture, improvement, re-socialisation

\section{Introduction}

Children's socialisation centres in Lithuania have been criticised for several years as a result of unchanging work with juvenile delinquents (Merkys et al, 2002; Šapelytė, Alifanovienè, 2009, Bakutyte et al, 2013). Owing to the rapidity of change in this context, the concept of re-socialisation and the role of these schools in the society have changed significantly. As Cameron and Quin (2011) stated, most organisational scholars have already recognised that organisational culture has a powerful effect on the performance and effectiveness of each organisation. These provisions are in line with the literature of school effectiveness and improvement (Terhart et al, 2013; Sammons et al, 2016), which emphasises the need to investigate the links between the school culture and socialisation. Nevertheless, using school as the primary unit of analysis, the main goal is to find the capacities to provide professional development rather than rely on an external transition model or to marginalise them (Chapman et al, 2016).

Van Gasse et al (2016) stated that a lot of studies showed schools to be different in terms of effectiveness and offered to refuse focusing only on children cognitive outcomes in the school culture researches. The mission of children's socialisation centres as specific schools is to re-socialise delinquent behaviour of children in order to help them to integrate into the society. Despite this, they are defined as general educational schools at the legal level and it requires defining the meaning of school effectiveness in a different way. From organisational point of view, school culture is related to the core values of the organisation, based on which it can be assumed that it directly influences the process of children's re-socialisation (Sakalauskas, 2015). However, there is a very little empirical evidence on school's capacities to improve the children's socialisation at organisational level and it is hard to find the analysis of the re-socialisation process in literature at all. As noted by Muijs (2013), 
the understanding of the importance of organisational culture is the first step during the organisational improvement process. According to the paradigm of school effectiveness and improvement, in order to define what needs to be improved, first of all, a current organisational culture has to be diagnosed. In addition to this, the aim of this study is to identify each socialisation centre's cultural profile by showing the features of implementation of re-socialisation process.

In this survey, school culture is defined as 'a system of fundamental values that underpins the activities of the organization and its members, which are supported, fostered and created by the organization's myths, stories and traditions' (Targamadze, 2006). This definition refers to values as a basis of culture, which acts as guidelines for the positive organisational behaviour. It corresponds to a functionalist approach and is based on competing values framework (Cameron, Quinn, 2011) as the validated model of organisational culture change. The study uses the School Culture Inventory (Maslowski, 2001) for the purpose to get a deeper understanding of the cultural characteristics of children's socialisation centres. The analysis of school culture is made by using approach in which quantitative data 'examines concepts in terms of amount, intensity, or frequency'(Ketokivi, Choi, 2014).

\section{Literature Review}

More than 40 years, the outcome of schooling and its effect on children's social, emotional and academic development have been the main topics in educational research. The scientists were discussing and rethinking the role of the school as an organisation as well as evaluating existing practices constantly in order to answer what is a 'good' school. Finally, they made a conclusion that each organisation is unique and transferring the positive experience to another context does not necessarily mean success (Hopkins, 2016). For that reason, school improvement ideas became more acceptable because of comparing dynamics of the school itself, not just the different schools with each other.

The idea of improving the activities of children's socialisation centres is also not new: for many years, it has been debated, what should be the role of these non-traditional schools in society? Children's socialisation centres as schools or organisations working with special target group were an object of educational research for the past few decades. However, the culture of children's socialisation centres has never been analysed as a separate concept. It is interesting that the culture of these schools has never been linked to the results - the successful re-socialisation of children.

According to Creemers and Kyriakides (2016), 'organizational theories often adhere to the position that the effectiveness of organizations cannot be described in a straightforward manner; instead, a pluralistic attitude is taken with respect to the interpretation of the concept in question'. It means that different approaches to effectiveness have a lot of models, which include various evaluation criteria. In this case, there is an approach (Scheerens, 1992) that the culture could be analysed by ordering the criteria of productivity or involvement according to external stakeholders. Another approach (Cameron and Quinn, 2011) argues that the criteria as competing values - this perspective concerns the distinction of all the possible aspects of school functioning that are important to reach the effect. The latter approach was chosen in this study using the universal model as methodology, which can be applied to the analysis of culture in the context of organisational performance.

Competing values framework (Cameron, Quinn, 2011) is theoretical framework for understanding organisational culture. It is especially useful for interpreting a variety of organisational phenomena in order to identify its performance and lead the cultural transformation. This model was created on the analysis of 39 indicators of organisational effectiveness, which represented 4 main clusters as quadrants of the model: (1) internal process, (2) human relations, (3) open system and (4) rational goal.

The part of 'internal process' is focused on values such as stability and predictability. It is believed that organisation can operate effectively when its actions are coordinated, that is why documentation and information management are understood as the most important priorities in order to reach the results. The second part is named 'humans relations', it is based on the idea that only high morale and concern for people can create an open atmosphere, which is needed to make the right decisions and 
effectiveness. The 'open system' represents the values such as innovation and adaptation, which are related to external environment. The main idea of this part is the responsiveness to change the conditions in the environment and further growth for ensuring support from stakeholders in the external environment. The 'rational goal' quadrant is based on the pragmatic approach and actions for achieving the organisational goals. In this context, the meaning of effectiveness is goal clarification, feedback and productivity.

This model also distinguishes two major dimensions: (1) flexibility control and (2) internal-external. The first one is differentiated effectiveness criteria that emphasise the flexibility and dynamism from criteria that emphasise stability and control. It means that the continuum is ranged from organisational versatility to organisational steadiness. Another dimension measures effectiveness criteria from integration and unity to differentiation and rivalry. This means that some organisations are effective if they are oriented to internal harmony whereas others are interacting with others outside (Cameron, Quinn, 2011).

The logic of this model is that each part of the model illustrates what people value is, what is good and appropriate in the organization, but their expression in every organisation is different. The strength of the culture of the organisation is associated with homogeneity and clear focus and thus shows that the specific culture type is dominant. Organisations may need a more balanced culture where every part of culture is in the similar level; however, such cases are rare. On the other hand, the balanced or eclectic profile of culture is usually interpreted quite negatively, that is, it explains that the organisation does not use its culture as an instrument to improve its performance (Maslowski, 2001).

The last important aspect of organisational culture is congruence when comparing the values of individual staff members and the school. The competing values framework emphasises the terms of the integrative approach to school culture, which is considered to be an important determinant of the effectiveness of any organisation. Cameron and Quinn (2011) argued that congruence predicts the success and high performance of any organisation because the strategy, leadership style and reward system are clear and based on the same values. The more these values are similar to the values of staff members, the stronger is the congruence.

\section{Methodology}

Sampling. As the sample size is very important for the statistic accuracy, it was determined by assessing the whole population with a 5\% sample error (Creswell, 2013). The sample size is determined by the following formula:

$$
n=\frac{1}{\Delta^{2}+1 / N}
$$

where

$n$ is the sample size

$\Delta$ is the error size

$N$ is the size of the general population

According to the data provided by the Centre of Information Technologies in Education in 2016-2017, children's socialisation centres had 199 employees. After the calculation of the received data, not less than 133 employees participates in the survey.

Respondents. The total respondent of the survey was 153: 9 management members, 53 teachers, 40 mentors, 18 specialists of educational assistance and 33 service staff members. The distribution of respondents according to the different institutions is given in Table 1. 
Table 1. The comparison between the total number of the employees in children's socialisation centres and the number of the survey participants (Source: author's compilation)

\begin{tabular}{|l|l|l|}
\hline Children's socialisation centre & Total employees & Participants (\%) \\
\hline 1 & 38 & $31(82)$ \\
\hline 2 & 43 & $28(65)$ \\
\hline 3 & 42 & $40(95)$ \\
\hline 4 & 39 & $28(72)$ \\
\hline 5 & 37 & $26(70)$ \\
\hline
\end{tabular}

Design. Quantitative data are obtained from the survey that is based on the School Culture Inventory (Maslowski, 2001). This instrument is constructed and validated for measuring school culture that reflects values expected to be related to school performance. It is based on the competing values framework consisting of four perspectives on organisation. Conceptually, these perspectives can be described by means of the focus of school and the emphasis on flexibility versus control. The focus of school can be aimed at internal or external issues: internal means that the school itself is the most important; external reflects the relationship between the school and the environment. Research shows four dimensions of school culture, which are labelled by human relations, open systems, rational goal and internal process orientation. This inventory is made up of 4 scales, each of them consisted of 10 items (values). They are valued according to the Likert scale based on the level of person and school from 1 (not important) to 5 (very important). All the items have to be valued at personal and organisational levels, which measures cultural fit (homogeneity and strength) between the values of individual staff members and the school values. In order to use this instrument, a double translation was made: English to Lithuanian and back translation to English.

Data processing. Date of the survey was from November 2016 to January 2017. There are five children's socialisation centres for identifying the cultural features of each institution. In order to be able to collect the data, a pilot survey was conducted, in which the staff from one children's socialisation centre were surveyed anonymously. To be able to survey as more members of each institution as possible and taking into account the organisational features of this school (continuous work, shifts of employees, etc.), the employees of the centres had a possibility to provide their data through the questionnaires during the visits or through the online version of the questionnaire.

Data analysis. The statistical processing of the data was made using a software suite SPSS 22.0; the received data were used to determine the total (averaged) estimate and instrument reliability (internal consistency) of Cronbach's $\alpha$ coefficient in the level of a person and school. The congruence was determined using the Wilcoxon criterion.

Limitations. This study helps to identify the essential features of school cultures, the congruence of staff members and school values but does not reveal the content of the culture. A deeper qualitative analysis of existing culture is necessary in order to design a vision of children's socialisation centres' improvement.

Ethics. During the analysis of the data, the names of the children's socialisation centres are anonymised in order to ensure the ethics of the survey, whilst the institutions are numbered from 1 to 5 to prevent the potential negative effect of the public data analysis.

\section{Results}

The reliability of the survey inventory was examined by determining the reliability of aggregated variables at human and school levels (Table 2). At the human level, this revealed satisfactory values for the open system and human relations. The rational goal orientation was found to be highly reliable $(0.909)$ and the internal process was relatively low (0.795). At the school level, all the coefficients of cultural orientations were sufficiently reliable; the highest reliability was shown by the rational goal 
and human relations subscales (0.922). Given the fact that the values of all coefficients are significantly higher than 0.6 , assuming that the homogeneity of the questionnaire is sufficient, the data of all subscales may be interpreted.

Table 2. The reliability of scales in personal and school levels. (Source: author's compilation)

\begin{tabular}{|l|c|c|c|}
\hline \multirow{2}{*}{ Subscale } & Number of items & \multicolumn{2}{c|}{ Cronbach's $\boldsymbol{\alpha}$ coefficients } \\
\cline { 3 - 4 } & & Person level & School level \\
\hline Open system & 10 & 0.887 & 0.869 \\
\hline Rational goal & 10 & 0.909 & 0.922 \\
\hline Humans relations & 10 & 0.859 & 0.922 \\
\hline Internal process & 10 & 0.795 & 0.870 \\
\hline
\end{tabular}

As it was mentioned, very little is known about the features of children socialisation cultures, which shows what is valued in these schools. For this reason, the survey results give the number of descriptive statistics for identifying the situation. Table 3 reveals that the hierarchy of cultural orientations are not the same in different schools - this emphasises the fact that the uniqueness of each organisational culture.

It is worth mentioning that all the cultural orientations of the first school are closed to the grand mean. Despite the fact that this children's socialisation culture shows rather similar mean score range for all subscales, human relations and internal process are relatively high rating. This indicates that teachers, school administration and other staffs value collegial relationships, commitment and stability. It can be argued that this organisation is least oriented towards changes and external requirements.

The second school culture demonstrates strong focus on internal process - this subscale reflects that school community is oriented towards predictability and control. The dominant feature of this school culture shows that teachers and administration value the formalisation of school processes, which regulates and coordinates the activities of individual staff members to be necessary. The mean scores of rational goal and human relations $(x=3.65)$ are slightly smaller than open system - all these cultural orientation seem to be less prominent at this children's socialisation centre.

The results indicate that the culture of a third organisation, similar to the first one, emphasises the importance of mutual relations, internal formalisation and continuity during children re-socialisation process. The mean scores of school on human relations and internal process orientations $(x=4.20)$ are greater than the values of the open system and rational goal orientations, ranging from 0.27 to 0.33 . The high focus on internal aspects demonstrates a relative isolation from external factors that change over time and require schools to exchange as well.

Table 3. The descriptive statistics of cultural orientation (Source: author's compilation)

\begin{tabular}{|l|l|l|l|l|l|l|}
\hline Cultural orientation & $\mathbf{1}$ & $\mathbf{2}$ & $\mathbf{3}$ & $\mathbf{4}$ & $\mathbf{5}$ & Total \\
\hline Open system & 4.24 & 3.68 & 3.87 & 4.00 & 4.01 & 3.96 \\
\hline Rational goal & 4.32 & 3.65 & 3.93 & 4.03 & 4.13 & 4.01 \\
\hline Humans relations & 4.39 & 3.65 & 4.20 & 3.99 & 4.10 & 4.08 \\
\hline Internal process & 4.35 & 3.90 & 4.20 & 4.15 & 4.18 & 4.17 \\
\hline
\end{tabular}

The fourth children's socialisation centre can also be characterised by a relatively strong internal process orientation, indicating that administration and teachers believe that the school can operate well when all the activities are clearly identifiable and coordinated. The other three cultural orientations 
related to both the external integration and internal human relations, as the data show, are probably not prioritised. Owing to the fact that one cultural orientation strongly dominates, it can be argued that culture can be described as strong.

The last cultural profile identifies the internal process $(\mathrm{x}=4.18)$ and rational goal $(\mathrm{x}=4.13)$ orientations as the priorities to the effectiveness of this school. The rational goal orientation in any of these schools has not been so appreciated - it indicates that the members of organisation value the demand of accountability and are inclined to realise their objectives. Given the fact that the average of open system orientation is the lowest one, it is possible that the school perceives the implementation of re-socialisation in its own way and the external requirements are not always the most important for it.

The general assessment of the data of all children's socialisation centres' cultures shows that these schools have a strong orientation towards internal activities $(x=4.17)$. In other words, all communities understand that the stability, continuity and coordination are necessary for the functioning of the institution. The average of the open-system orientation is the smallest one $(\mathrm{x}=3.96)-$ this also indicates that the members of organisations are far less inclined to implement educational reforms and changes. What is more, it should be mentioned that the staff valued the rational goal orientation rather low $(\mathrm{x}=4.01)$. This indicates that management, teachers and specialists are less likely to appreciate the quality of work, that is, the reputation of the institutions according to its performance and use of external resources. Meanwhile the importance of cooperation and good interpersonal relationships were valued fairly high $(\mathrm{x}=4.08)$. Thus arguments that trust, understand and solidarity are considered to be significant features of school teams during the re-socialisation process.

The two last criteria (summarised in Table 4) consist of the dimensions of competing values framework and cultural fit (congruence). These data demonstrate which cultural aspects of school communities are prioritised in order to achieve the effectiveness of school performance (successful resocialisation of students). It will also help to identify whether the values of the school and the people working there are the same - as already mentioned, this aspect is considered to be very important when diagnosing the culture because of a work practice improvement.

Table 4. The school cultural features by dimensions and the congruence (Source: author's compilation)

\begin{tabular}{|l|l|l|l|}
\hline $\begin{array}{c}\text { Children } \\
\text { socialization centre }\end{array}$ & Internal vs external & Flexibility vs control & $\begin{array}{l}\text { The congruence of personal and } \\
\text { school levels (cultural fit) }\end{array}$ \\
\hline 1 & Internal & Equally & 3 cultural orientations coincide \\
\hline 2 & Equally & Equally & No cultural orientation coincides \\
\hline 3 & Internal & Equally & 1 cultural orientation coincides \\
\hline 4 & Equally & Control & No cultural orientation coincides \\
\hline 5 & Equally & Control & 1 cultural orientation coincides \\
\hline
\end{tabular}

The comparison of cultural profiles in the model of competing values framework dimensions (internal vs external and flexibility vs control) have shown that school culture profiles are different and can be grouped together according to the dimensions. The answers of staff members of the first and third children's social centres are similar: they show strong orientation towards internal processes, whilst the dichotomy of flexibility and control is assessed equally. Meanwhile, the cultural features of the fourth and fifth children's socialization centres coincide contrary: internal and external dimensions are equally distributed, but both schools exhibit a high level of control. In this regard, the two pairs of children's socialisation centres are contrasting in the same way. Only the profile of the second school's culture was different from others because its results were distributed equally in both dimensions of culture.

Finally, the congruence of individuals and school values is analysed. According to this criterion, the second and the fourth schools can be described as completely unfit for all cultural orientations. In the third and fifth schools, only one cultural orientation coincides in the personal and school levels. The 
first centre of children's socialisation is distinguished by the greatest cultural coherence: the assessment of only one cultural orientation is controversial. When analysing the content of cultural orientations, it should be noted that the contrast can be seen amongst the first and fifth children's socialisation centre, as the employees of the first school controversially assessed the orientation of the internal process, whilst the staff in the fifth school was only united on the orientation of the internal process; this indicates the differences not only in the balance of values but also in the importance of the process of the re-socialisation.

\section{Conclusions}

According to the paradigm of school effectiveness and improvement, school culture, regardless of the concept of performance effectiveness, must be oriented towards change because of the changing society and the new challenges the education face. Throughout the working period of the children's socialisation centres, the concept of re-socialisation has significantly changed because of the changing attitude to juvenile delinquents: earlier, it was intended to isolate them from the society, it is now internationally assumed that such behaviour is caused by various risk factors that need to be reduced or eliminated by providing assistance to make it easier for them to integrate into the society.

The cultural profiles of children's socialisation centres have a strong orientation to sustainability and avoidance of changes whilst confirming that the culture of these schools is not oriented towards the modern content of re-socialisation. It can be added that such a feature as a high level of formalisation of activities is basically not favourable for re-socialisation because of the strict structure, not giving the students the opportunity to learn autonomously, not empowering them to plan, act and make decisions by themselves. Probably, the culture as a factor of experience protection and inertia makes it possible to operate because it is known and tested. These data also confirm the opinion of Fullan (2007) on changing school practices in which the ongoing reforms are aimed solely at restructuring rather than replacing cultural aspects.

The research results show that schools could work in two main directions in order to improve their performance and achieve results. First, the communities need to promote the use of external resources and they should have a clear agreement on what and how it should be achieved in the process of resocialisation, in order to meet the expectations of the country as well as the society. Schools have to become more open-minded and not only follow their own experiences but also to come up with a wider vision for the implementation of re-socialisation. Second, it is equally important that the values declared by the members of the community and the school are the same - according to the results, most of the school staffs are not in favour of the school's working practice. This means that the potential of employees is not fully used; it might be that employees have innovative ideas but they are not heard or implemented - strong orientation is usually associated with autocratic management of the institution.

\section{References}

Alifanovienė, D., Šapelytė, O. (2009). Nepilnamečiu resocializacijavidutinę priežiūrą vykdančioseinstitucijose: pedagogų požiūris [Juveniles' resocialisation at medium supervision institutions: educators' viewpoint].Socialinisugdymas, (20), 84-97.

Bakutytė, R., Geležinienè, R., Gumuliauskienė, A., Juodraitis, A., Jurevičienė, M., Šapelytė, O. (2013).Socializacijoscentroveiklosmodeliavimas: $\quad$ ugdytiniuresocializacijosprocesuvaldymasirmetodika [Modeling the Activity of the Socialization Center: the Management and Methodology of the Process of Students Re-socialization]. Vilnius: BMK leidykla.

Cameron, K.S., Quinn, R.E. (2011). Diagnosing and Changing Organizational Culture: Based on the Competing Values Framework (3rd ed.). San Francisco, CA: Wiley.

Chapman, Ch., Muijs, D., Reynolds, D., Sammons, P., Stringfield, S. Teddlie, Ch. (2016).Educational Effectiveness and Improvement Research and Practice: the Emergence of Discipline, 34-57. The Routledge International Handbook of Educational Effectiveness and Improvement. New York: Routledge. 
Creemers, B., Kyriakides, L. (2016). Theory Development in Educational Effectiveness Research, 182-205. The Routledge International Handbook of Educational Effectiveness and Improvement. New York: Routledge.

Creswell, John W. 2013. Qualitative Inquiry and Research Design: Choosing Among Five Approaches. Third edition. Washington DC: Sage.

Fullan, M. (2007). The new meaning of educational change, 4th Edition. New York: Teachers College Press.

Hopkins, D. ( 2016). School Improvement and System Reform, 157-181. The Routledge International Handbook of Educational Effectiveness and Improvement. New York: Routledge.

Ketokivi, M., Choi, T. (2014). Renaissance of Case Research as a Scientific Method. Journal of Operations Management, (32), 232-240.

Maslowski, R. 2001. School Culture and School Performance. Twente: Twente University Press.

Merkys, G., Ruškus, J., Juodraitis, A. (2002). Nepilnamečių resocializacija. Lietuvos nepilnamečiu priežiūros îstaigų psichosocialinè ir edukacinè situacija. Vilnius: Všt Šiaulių universiteto leidykla.

Muijs, D. (2013). Collaboration and Networking Between Schools. Presentation at the VI Seminario Internacional de la Red de Escuelas Líderes, Santiago, Chile, 5 July.

Reynolds, D., Teddlie, C. (2000). The Processes of School Effectiveness. The International Handbook of School Effectiveness Research, 134-159. London: Falmer Press.

Sakalauskas, G. (2015). Kalinimosąlygos ir kalinių resocializacijos prielaidos. Teisés problemos, (2), 5-53.

Sammons, P., Davis, S., Gray, J. (2016). Methodological and Scientific Properties of School Effectiveness Research, 58-109. The Routledge International Handbook of Educational Effectiveness and Improvement. New York: Routledge.

Scheerens, J. (1992). Effective Schooling: Research, Theory and Practice. London: Cassell.

Targamadzè V. (2006).Konfliktųkontūrųbrëžimas: ugdymorealybèskontekstas [Conflict Contours: the Context of Educational Reality]. Vilnius: Vilniauspedagoginiouniversitetoleidykla.

Terhart, E. (2013). Teacher Resistance Against School Reform: Reflecting an Inconvenient Truth. School leadership and management, (33:5), 486-500.

Van Gasse, R., Vanhoof, J., Van Petegem, P. (2016). The Impact of School Culture on Schools' Pupil Wellbeing Policy-Making Capacities. Educational Studies, DOI: 10.1080/03055698.2016.1195718, 1-17. 